\title{
The Aesthetic Feeling in Javanese Islam
}

\author{
Sulaiman Dufford \\ International Islamic University Malaysia, Malaysia \\ E-mail: sulaiman4444@yahoo.com \\ Zahid Emby \\ Universiti Putra Malaysia, Malaysia
}

\begin{abstract}
Our examination of Javanese Islam has attempted 1) to assess aesthetics as a major component of religious revelation, 2) to establish aesthetic elements as major factors in motivating religious conversion into Islam for the Javanese (or others), and 3) to delineate aesthetic elements as stimulants to subsequent spiritual growth for the born-Muslims. We attempt to describe a highly sophisticated sensitivity to aesthetic elements within their religious rites and rituals among the village Javanese, along with sometimes eloquent expressions of these understandings. Hopefully, our results will serve to inspire further studies of aesthetic rather than theological validation of Revealed or Prophetic Knowledge, a form of cognition and knowledge long familiar to traditional religious cultures that is now coming to be considered a valid form of reality even in the western world, by such influential scholars as Leo Strauss.
\end{abstract}

Keywords: Psycho spiritual study, Exoteric aesthetics, Esoteric aesthetics, Jinn, Synchronicity, Aesthequity, Aesthetic sensibility, Oral spiritual history

\section{Models of Value-Based Aesthetics}

There are numerous scholarly works in the western world that have contributed over the years to the general understanding of the 'aesthetic experience', and its importance to the individual human psychology as well as the social community, one of earliest being that elaborated by Aristotle (Dufford, 2004). Then around the turn of the twentieth century (1896), a series of lectures was given by philosopher George Santayana at Harvard University. These are now a classic in aesthetic theory, published under the title, 'The Sense of Beauty' (Santayana, 1961). Here are some of his more memorable comments that will lead us directly into Islamic aesthetic theory:

The philosophy of beauty is a theory of values... To know the truth about the composition and history of things is good... Because of the enlarged horizon it gives us, because the spectacle of nature is a marvelous and fascinating one, full of a serious sadness and large peace, which gives us back our birthright as children of the planet and naturalizes us upon the earth.

Not only are the various satisfactions which morals are meant to secure aesthetic in the last analysis, but when the conscience is formed, and right principles acquire an immediate authority, our attitude to these principles becomes aesthetic also. Honor, truthfulness, and cleanliness are obvious examples. When the absence of these virtues causes an instinctive disgust, as it does in well-bred people, the reaction is essentially aesthetic, because it is not based on reflection and benevolence, but on constitutional sensitiveness. This aesthetic sensitiveness is, however, properly called moral, because it is the effect of conscientious training and is more powerful for good in society than laborious virtue, because it is much more constant and catching. It is... the aesthetic demand for the morally good, and perhaps the finest flower of human nature.

Badri (2000), distinguished Sudanese psychologist and writer, has referred to the importance of the aesthetic element in a recent translation from the Arabic original of his 'Contemplation - An Islamic Psychospiritual Study':

The Qur'an also urges people to contemplate the Divine signs in the universe by awakening the innate aesthetic sense in them. The following verses aim to arouse people's genuine feelings and emotions so as to enable them to observe the beauty of everything on the earth - whether the various colors and shades, plants, animals, or even inanimate objects: 'Do you not see that God has sent down rain from the sky, whereby We 
have brought out produce of various colors? And in the mountains are tracts white and red, of various shades of colors, and black intense in hue. And similarly among men and crawling creatures and cattle who all have various colors. Those who truly fear God among His servants are those who have knowledge. For God is Exalted in Might, and is Oft-Forgiving' (35:27-28). We also find verses where the Almighty, after showing His favors to humanity in creating the cattle for their sustenance and use, reminds His slaves to contemplate their beauty: 'And He has created cattle for you. From them you derive warmth and numerous benefits, and of their [meat] you eat. And you have a sense of beauty in them as you drive them home in the evening and as you lead them forth to pasture in the morning' (16:5-6). 'He Who has made everything which He has created most good and beautiful' (32:7).

Badri (2000) divides Islamic contemplation into four stages, the first being knowledge through direct sensory perception or indirectly through imagination. Some scholars refer to 'left-brain' cognition to indicate what we study and analyze in such a way. The second stage begins as one takes a closer aesthetic look at these data, in which we shift to a state of wonder at the beauty, excellence, and refined structure of the perceived object ('right-brain' cognition). Here is where 'aesthetic sensibility', innate or acquired, assists us to the third stage of the process, contemplation of the Godhead, which in turn finally leads us to the fourth and final stage of 'spiritual cognition' (shuhud). Badri (2000) further explains:

... the second stage, that of appreciating the beauty of form and structure, can touch the hearts of both believers and unbelievers. However, the third stage, which relates this aesthetic appreciation of the universe to the Almighty Creator, can only be achieved by believers. As for the believers who reach the fourth stage, they are in such deep veneration and remembrance of God that they can no longer look at God's creation in a detached manner; they see nothing but precision, mercy, beauty and wisdom in the structure of the world...

The renowned Islamic scholar Qutb (1979) attempts to evoke an aesthetic appreciation of the universe in the following excerpt from his Qur'anic commentary, 'In the Shade of the Qur'an:

This world is beautiful, inexhaustibly beautiful. Man may grasp and enjoy this beauty as much as he wishes, and as much as the Creator of this world wishes. The element of beauty in this world is intentional. Perfection of creation results in achieving beauty. The perfection of creation is apparent in the beauty of every organ and every creature. Look at the bee, the flower, the star, the night, the morning, the shades, the clouds, this music pervading the entire universe of beauty and perfection. The Qur'an draws our attention to all this, so we may ponder and enjoy it. Hence: 'He Who has made everything that He has created most good,' is a verse which arouses the heart to trace the aspects of beauty and perfection in this great universe.

In addition to Qur'anic verses that encourage contemplation of the beauty of the heavens and earth in general, we also find verses which mention the aesthetics of human nature:

'We have indeed created man in the best of moulds' (95:4), and, 'He has created the heavens and the earth in just proportions, and has given you shape, and made your shapes beautiful, and to Him is the final goal' (64:3).

Here are some comments by Qutb (1979) referring to these and other such verses::

Man is the greatest wonder on this earth, but he is inattentive to his own worth and inherent mysteries when his heart is inattentive to faith, and when he is denied the favors of certitude. He is a wonder in his body formation: in the secrets of this body, in his spiritual formation and in the mysteries of his soul. He is a wonder within and without, as he represents the elements of this universe. You claim you are a microcosm, while you contain the macrocosm. Whenever man contemplates himself, he is faced with astonishing and bewildering mysteries: the formation of his organs, their positions and functions; the way the functions are executed; the mysteries of his soul, and its known and unknown energies; how he forms his concepts and the way they are stored and remembered. All these images... where and how are they stored? These images, visions and sights... how are they recalled? What is unknown of these images is immeasurably more. Then there are the mysteries of humankind, in its propagation and succession: one cell carries all the characteristics of the humankind, including those of the parents and forefathers. Yet where do all these characteristics lie, in such a tiny cell? And how does that cell recreate them minutely, ending with a reproduction of this wonderful human being?

For an Asian, specifically Malaysian Muslim interpretation of aesthetics, we can refer to contemporary Malay painter, Sulaiman Esa, holder of a Ph.D in Islamic Studies from Temple University, Philadelphia, USA. In conjunction with an exhibition of his paintings at the Petronas Gallery in Kuala Lumpur in March of 2001, Sulaiman published an article in the exhibition catalog, entitled, 'Islamic Roots of the Malay Philosophy of Beauty'. Sulaiman introduces his summary of the five basic attributes or principles that constitute the Islamic - based Malay concept of the beautiful:

...the Malay-Sufi notion of the beautiful reveals that semantically, the term beauty possesses dual aspects - the external and the internal. The first is defined by the term indah and the second by the term elok. While indah emphasizes the external, the manifested, the sensually perceptible aspect of the beautiful, elok, refers to the 
internal, hidden and the essential... Specifically, elok equates the concept of goodness in its moral-spiritual sense... True beauty, Al Ghazali believes, is not limited or restricted to that 'which can be seen with the eye, or be perceived with the five senses. It must also appeal to the sixth sense, the soul, which is also the heart, spirit, the inner light (Catalog for Exhibition, 2000).

Sulaiman (Catalog for Exhibition, 2000) continues to quote Al Ghazali in drawing the comparison between the inner and outer beauty, much as we will do presently:

The inner beauty is far superior to the outer beauty. For the beauty of the outer form which is seen with the bodily eye can be experienced even by children... but the beauty of the inner form can only be perceived by the eye of the heart and the light of man alone.

From a perusal of a number of writings by scholars, Sulaiman suggests five attributes that constitute the Malay concept of beauty (Catalog for Exhibition, 2000). Halus, or the principle of refinement, occupies the highest position in the hierarchy of values in Malay aesthetics. It signifies aesthetic qualities such as subtlety, complexity, and intricacy. This involves a profound empathy and a masterly control existing between the artist and his chosen medium.

Lembut, or the principle of flexibility, refers both to the actual approach to art, as well as to artistic sensibility - the overall mood and feeling engendered by the artwork itself. In the first case, lembut denotes the absence of violent or aggressive force or energy in a design or execution. In the second, lembut suggests such qualities as softness, gentleness, and tenderness.

Seimbang, or the principle of balance, involves the Malay sense of order and ideal composition, which should express grace, harmony, and tranquility. This is also an ethical-spiritual teaching of Islam, known in Arabic as mizan, or peace, harmony, and submission as the guiding principles in one's life. According to Al Qur'an:

'He hath created man. He hath taught him power of expression. The sun and moon are made punctual... and

He has set the balance, that ye exceed it not, nor fall short thereof, but observe it strictly' (55:1-13).

The fourth principle, berguna or functionality, means that the practical function of the artwork defines its beauty, especially the collective sharing and egalitarian purpose that it may serve. Even in music, its therapeutic effects whether relaxant or energizing - are of interest. We may look at the Malaysian Philharmonic Orchestra, for example, as an inspiration and attraction to the management talent that Malaysia hopes to bring back to the country, reversing the 'brain drain'.

And finally, bersimbol or symbolism, enables Malay art to serve both the practical/material and moral/spiritual needs of the society. Thus, traditional art functions as counterpoint, or handmaiden, to religion:

Through the use of religious symbols and transcendent archetypes, art performs the didactic role of reminding man of his spiritual and theomorphic origin, his duty and purpose on earth, and his ultimate destiny. ${ }^{24}$

\section{A Qur'anic Model}

To our knowledge, research on the common people's aesthetic views has not yet been done from the exclusively Islamic point of view. To facilitate such research, we now consider a more holistic approach. As mentioned above, Sulaiman requires Muslims to distinguish an exoteric from an esoteric philosophy of beauty. Following Sulaiman's lead, we may now proceed to establish our conceptual system within the framework of a Qur'anic model which examines both exoteric and esoteric aesthetics, including some issues in the ethics of aesthetics, as so dreaded by secular theoreticians.

For clues as to our 'outer' (exoteric) Islamic aesthetics, we turn to Al Qur'an, Surah 94, 'Insyirah', in its entirety:

'Have We not lifted up and expanded your heart and relieved you of the burden which weighed down your back? Have We not given you high renown? Every hardship is followed by ease. Every hardship is followed by ease. When you have finished (taking your pleasure), resume your toil, and seek your Lord with all fervor.'

We see that our exoteric model strives for simple relaxation as the proper aesthetic goal, and that Al Qur'an promises 'Insyirah' as a more or less inevitable reward for enduring difficult experiences or subjective states. Such relaxation may be physical, emotional, neural, or even spiritual, as long as it penetrates deeply enough to compensate for the price of previous effort. It is one of the functions of artistic beauty to induce such relaxation in heart, mind, or soul. Any decently conceived music, for example, can serve this function without theological distress.

In our esoteric model, on the other hand, no prior striving is required. The goal of 'inner aesthetics' is insight rather than stress reduction. When an experience of beauty penetrates deeply enough into the human soul, we call it 'sublime beauty'. We may then experience some sort of profound understanding of ourselves or of life. Insight itself may take verbal form although the process by which it is gained cannot be premeditated, and it may not even be verbal.

Insight is not reliably achieved by targeting, even in psychotherapy. By such standards as these, Islamic 'ilham', or individual inspiration, is ultimately an aesthetic experience. The 'Qodar Ilham' at the end of Ramadan is an aesthetic 
experience involving profound insight. Our model of 'inner aesthetics', therefore, tends ineluctably to the value-based spiritual.

Let us summarise, then, what we mean when we refer to an inner aesthetic experience. What would be the phenomenological elements of such an experience? Our experience shows us that the psychological concomitants of an experience of 'sublime beauty' may be any or all of the following:

1. Internal verbalization stops. One's mind is at peace.

2. Trivial chatting stops. If one speaks, one speaks the truth.

3. Casual socializing stops. One relates deeply or not at all.

4. Trivial routines become effortless. There is no grasping.

5. One moves quietly with no haste. The body is deeply relaxed.

Subjective concomitants may be any of the following:

1. Random near-future concerns disappear. Tomorrow will take care of itself. One cherishes the fullness of the present moment.

2. Human faces become fascinating and beautiful.

3. For the moment, one is purged of prejudice and social distaste.

4. The 'unity of the cosmos' seems imminent.

5. Profound new insights or understandings flash before one.

6. One may shed quiet and private tears of gratitude.

These phenomena may of course apply to any aesthetically impactful experience. Humanistic Psychologists have added a lot to our profiling of the aesthete in his throes or at least moments of aesthetic happiness. Yet western secular writers have not been notably successful in describing value-based aesthetics, especially as the aesthetics of corner-church services and mentalities are so often aesthetically deficient. We turn, then, to an attempt at Islamically-based aesthetics.

\section{Aesthetics in Islamic History}

For one of the classic aesthetic experiences of religious conversion literature, we know that the Prophet's companion Umar Al Khattab (a.s.) experienced a total annihilation of his murderous hostility to Islam and the Prophet (s.a.w.), when he overheard a beautiful recital of Al Qur'an. He was on the way to murder the Prophet, but upon passing his sister's house wherein the Qur'an was being recited, his heart melted and he immediately embraced Islam.

The exoteric understanding of Umar's 'rebirth' states its cause as hearing a skilful recital of Al Qur'an, by coincidence. An esoteric understanding goes further. Retrospectively, this 'coincidence' was a miraculous simultaneity of the external event of the Qur'an reading with the internal susceptibility of Umar as he arrived outside his sister's house at precisely the right moment to have his life, and indeed, the history of the human race, changed forever. Perhaps his sister 'felt' or was moved to have Qur'an recited at the moment her brother was passing by, in the classic right-brain manner of being moved to do something significant without necessarily understanding why. This is far removed from conscious intention or goal-setting.

We might look at Umar's conversion experience in the light of Carl Jung's concept of Synchronicity - an 'acausal connecting principle' - to explain Umar's conversion as due to something other than the coincidence of passing his sister's house at a certain moment. Or we can refer to Ornstein's (1997) description of right-brain cognitive modes that derive spiritual meaning from simultaneity of images rather than from sequencing of events. Abraham Maslow, modern Humanist Psychologist, would call this a classic 'peak experience' signified by a completely spontaneous and radical value and behaviour change.

American psychologist William James might call Umar's conversion a 'rebirth' experience. He classifies all religious people as 'once-born' and 'twice-born'. In the Jamesian conversion model, Umar is a classic example of a 'twice-born' soul, whose entire religious outlook (more, perhaps, than a mere 'paradigm') is massively shifted by a single, overwhelming experience, such as that of Saint Paul on the road to Damascus.

\section{Fieldwork in Central Java: Islamic Rites and Rituals}

Moving into our more recent research, it must be mentioned that although most traditional anthropological research is carried out within a single circumscribed location, the following fieldwork was done in a larger collection area in Central Java. Yogyakarta served as an education-intensive site, whereas Solo was investigated as the de facto cultural center of the Javanese people, and several villages were visited to represent the 80 percent village population that make up the backbone of Javanese life, what Geertz called 'abangan' Muslims, that is, Muslims whose belief and religious identity is strong even without strict observance of the rituals. 
Highlighting the aesthetic elements in people's daily activities evolved into a four-part categorization, hopefully useful to future researchers in this largely untouched field:

1. The Aesthetics of Religion and the Unseen

2. The Aesthetics of Femininity

3. The Aesthetics of Music and Entertainment

4. The Aesthetics of Architecture and the Environment

Our investigation of the aesthetics of religion and the unseen, as highlighted by the present paper, involved rituals and modes of worship, as well as core beliefs, experiences of magic, and the world of spirits and angels. We begin with rites and rituals.

'When I am walking silently along toward the mosque in the early morning, dressed in my Arab juba and white cap, batik draped about my shoulders, I feel whole and complete. I feel this is no role or costume. This is ME. This is the dignity of my older age, a dignity that is satisfied in no other way, at no other time, so fully. When I pray together with a few other men from the neighborhood, I feel on the front line of protection for the coming day, old as I am. I feel deep respect for these men, whom I may hardly know socially, who have troubled themselves to arise at $4 \mathrm{am}$, disturb their sleep, and face the One God in closed ranks like this. The sound of the prayer-call, the sound of the Imam reading the Qur'an, these sounds are special to Islam and can be found nowhere else. They are not elaborately 'beautiful' like some types of music or singing. They are not excessively solemn. They are not ostentatiously sober or pious, nor are they merely neutral. If you ask me, they are the essence of the Islamic aesthetic.'

This was a Javanese village grandfather in Dusun Ngasinan (Solo area), whom I observed attending the early morning prayer (around $4 \mathrm{am}$ ) very regularly. Walking to the mosque, his body language seemed to express something of what I have found among the more stable and dedicated Muslims, regarding the perception of aesthetic elements in their routine rituals of worship. Their perceptions seem to express an aversion to excessive affect, a comfort in the steady devotion to the daily flow of normal life. His walk to the mosque was more of a glide. It had an aesthetic component which was very smooth, assured, and really very civilized.

Here is the report of a younger Javanese returning from Mecca, whom I met deplaning from his Hajj in the Jakarta airport, surrounded, as is usual for Indonesians, by his loving family who had come to meet him and share immediately whatever 'presence' ('baraka' in Muslim Arabic terminology) he may have brought back from the Pilgrimage:

'It's difficult for me to say what was most beautiful in my visit to the Holy Land. My first view of Al Ka'aba in Mecca brought tears to my eyes and a tremendous reminder of the essential unity of all our prophetic religions. A voice seemed to be chanting in my mind, 'One God, One God, One God, One God', and my Christian friends and relatives were included in this remembrance. We say we worship 'the One God' but maybe we really do not think of our Muslim God as exactly the same as that of the Christians and the Jews, I don't know.

Although this was a beautiful experience, it was not an experience of beauty as such. My deepest experience of beauty came in Medina. There, I burst into tears, really copious tears compared to Mecca, and I could not take my eyes and hands off the excruciating beauty of Al Qur'an itself. Then I prayed and was granted a vision of the incredible beauty of the Prophet's Sunnah, if taken as a complete system and understood broadly enough. Then, while I was looking around the exquisite interior of the Masjid An Nabawi, I was granted another vision of the source of all this Islamic beauty in the person and personality of Rasulullah himself (s.a.w.). I had never seen such beauty in a human male before. And this beauty was universal, it was not limited to male or female. It was the way we should be, as human beings, and it was quite different from what we think of as womanly beauty. This experience has helped me to remember the potential beauty of all my Muslim brothers and sisters back home here.

In response to the question, 'What is the most beautiful moment of the Muslim religious year?' A young woman meeting her family on the returning Hajj flight replied:

'It was when I went to the airport to meet my parents and others coming back from their Hajj in Mecca. All the people who came to meet their returning families seemed overflowing with love and happiness when the Hajji passengers came out of Immigration. I saw one young Hajji protecting his young wife so carefully as they came out, wheeling their baggage before them, placing his wife between himself and the baggage cart. Maybe this couple will be married forever, it looked like that. Before my own parents came out, I just stood there feeling like I was in Mecca myself. It was wonderful. Then, when my mother and father appeared, I understood how important they are to me, and why we are always taught to kiss their hands and bow before 
them in humility. Next to Allah swt., they are the source of life to us on this earth! I hope my own children feel the same way about me. Maybe if go to Mecca later, they will.'

Certainly we cannot dispute that warm moments between children and their parents may be described as beautiful moments. Indeed, such beauty is a real hallmark of rapprochement between the generations.

Such inter-generational rapprochement is also served when Javanese Muslims practice a 'forgiveness ritual' in the Idul Fitri celebrations following the fasting month of Ramadan. The Javanese word for this ritual is 'sunkem', and it consists of the family elders seated in a prominent place in the home, receiving all members of the younger generation in respectful genuflection, touching the elders' hands or placing their foreheads on the elders' knees, and asking forgiveness for all their mistakes and offences to the feelings of the elders over the previous year. One young Javanese male in Dusun Ngringin (Solo) reported:

'(My most beautiful moment) is when I ask my parents and grandparents for forgiveness after Ramadan. We put on our beautiful new clothes and visit all our relatives. When you pray to Allah for forgiveness, sometimes you don't know if He hears your prayer. It's easier to feel forgiveness from your parents.'

Let us move on to examine the aesthetics of Islamic fasting, and its close association with Qur'anic recitation. Every year during the month of Ramadan, the Holy Qur'an is recited by memory from cover to cover, by the Imams of Mecca and Medina. Hundreds of thousands of Muslims arrive and stand respectfully and silently while these Imams dedicate their minds and hearts to the performance of this recital, thereby assuring the oral preservation of this document that is absolutely unique in human history.

If you ask Muslims the purpose of their Ramadan fasting, you get various answers: 'It is practice in self-restraint', 'It teaches us to pity the poor', 'It teaches us to be less angry and critical', 'It teaches us to feel how the poor and hungry feel', 'Allah swt orders us to do it for His Pleasure'.

In addition to these inner benefits, however, the Ramadan also provides Muslims an opportunity to hear the Holy Qur'an recited in perfect style and syntax from cover to cover. This is what goes on at Mecca and Medina during those thirty consecutive Ramadan nights. This is why there are little marks in every Qur'an, dividing it up into thirty equal sections (each section called a 'juz'), so that its recitation can be evenly distributed over the thirty nights of the Ramadan fast.

And the pure beauty of this annual oral recitation, which is nothing less than an oral spiritual history of the entire human race, is why Muslims all over the world gather in their mosques after their evening meals, to pray not only the requisite evening prayers together, but also to hear one 'juz' of Al Qur'an that is supposed to be recited during the extra prayers that follow. A sense of 'duty' by itself cannot possibly explain the motivation to stand more than an hour each night, head bowed, as the Revelation is recited entirely by memory by the Imams of the Muslim Mosques all around the world.

Unfortunately, many Imams in Malaysia and Indonesia nowadays recite only short bits of Qur'an as a minimum requirement for praying together after a long fasting day. However, Indonesian Muslims have a religious lecture or sermon each night of Ramadan, which provides an excuse to gather together and see one's friends, and also provides much-needed income for the many professional speakers who rotate among the mosques during pleasant Ramadan evenings.

Nevertheless, such practices still fall quite short of the fundamental aim of keeping the Qur'an alive in an oral tradition has existed unbroken for the past 1400 years. Students of hemispheric brain function should be able to appreciate the importance of sustaining a Holy Book that is sung privately or communally in a sophisticated art form, as well as read and studied for its intellectual content.

These Ramadan prayers in which one thirtieth of the Qur'an should be recited each evening are not obligatory upon the Muslims (Shahih Bokhari, 1907; Shahih Muslim, 561). Yet many, including this author whenever possible, follow the Meccan and Medinan recitations yearly with great fervor and devotion. These recitations are broadcast live to Muslim countries worldwide on radio and TV, making them accessible to virtually all Muslims who wish to partake of this incomparable feast for the eyes, ears, and deepest inner soul.

For the eyes, the exquisite work of the Saudi TV cameramen also continuously displays the aesthetic magnificence of the Mosque at Mecca. From inside the Mosque, the Imam can be seen carrying out his amazing feat of memory and worship, while the mosque architecture and design can be appreciated from high up upon the minarets, and from many angles and positions in the mosque area. Here is worldwide access to the beauty of Islam from the heartland - an aesthetic celebration totally unknown to westerners.

Localized celebrations of the beauties of the Qur'anic recital is organized all over the Muslim world by means of Qur'an reading festivals that select the most skilful readers from local, then national, then international levels. International experts in Qur'anic recitation meet yearly in Kuala Lumpur, Malaysia, to perform before public audiences 
and a panel of judges who evaluate their readings according to a most rigorous set of criteria - no less rigorous than any western artistic or Olympic competition. The International Qur'an Reading Festivals held in Malaysia are possibly at the highest levels of 'Islamic culture' that can be found today.

Such festivals are also held in Cairo, some of the Arab Emirates, and elsewhere in the Muslim world. Most of these display the talents of both men and women, although some are limited to men, in deference to cultural preferences. Reasonably (to Muslims), some men do NOT want the attention of a roomful of audience participants to be focused upon their wives or daughters in such a prominent manner.

In Egypt, one may feel a bit in awe of the Qur'an reciters' abilities to move large audiences. Several square city blocks are sometimes closed to traffic while thousands or tens of thousands of Cairenes assemble to hear such reciters. One of these, Sheikh Mohdammad Jibril, was brought to Malaysia by the then-Prime Minister Mahathir Mohamed for some Ramadan nights a few years ago. Several thousand Malaysians were brought to tears by Sheikh's recitations and prayers, yet meeting him afterward showed him as nothing more than a perfectly normal human being, no different really from everyone else.

Several years ago, random assignment of participants in the Malaysian Qur'an Reciters' Festival coincidentally called Egyptian, Iranian, and Indonesian contestants to recite one after the other. These three countries have long been renowned for the power, elegance, and inner beauty (respectively) of their recitations. The Egyptian recited with the vocal power for which his national groups are so well known. The Iranian then outdid himself in that special, ecstatic style that seems unique to the Persian soul. I was beginning to feel sorry for the Indonesian coming up next. How could he hope to compete with these champion reciters?

Everyone in that great hall was literally dumbstruck by what that little Indonesian from Sumatra did. As performing artists sometimes say, 'He had the audience in the palms of his hands'. Aside from his obvious technical expertise, he brought honor to the Indonesian name, at a time when media reports regarding that country were uniformly negative. He was awarded the international male championship that year, as we all guessed he would be. He was given a Hajj to Mecca, as well as a cash prize.

By means of these anecdotes, we can begin to realize the aesthetic impact of various of the Islamic rites and rituals, yet we may have strayed a bit into the realm of the 'superstars'. We return to one of our Yogyakarta respondents, a young woman from the district known as 'Kauman', which is behind the Palace Mosque. There is very little activity in Kauman after nine in the evening, no foreigners, and no business whatsoever. It seems an ideal place for young Muslim women to live. The evening silence is palpable, and perhaps may contribute to the sensitivity of the residents who take pride in living 'in the shadow' of the Royal Palace itself:

'Which is your favorite Mosque in Yogyakarta and why?' 'The Palace Mosque, because it has the most beautiful chair for the Imam to sit in when he rests.'

An aesthetic play-of-light is common to houses of worship in all religions. The Kraton (Royal Palace) Mosque in Yogyakarta is a good example. I also was particularly struck by the chair where the Imam sat down for his customary few moments of rest in the middle of delivering his sermon. In most mosques, such a chair is plain and functional and hardly noticeable.

Yet when one attends Friday Prayer in the Yogya Palace Mosque, one sees a veritable throne, jewel-encrusted, reflecting light in myriad beautiful ways. Once again, we can find glimpses from the West of the significance of one of our traditional Islamic practices, i.e., the sitting in the chair during the Friday sermon.

Harvard Professors Richard Alpert (later, Baba Ram Dass) and Timothy Leary used a watch alarm to stop themselves every ten minutes during their joint lectures of the mid-sixties. Wherever they were in their lecture, they would sit down for a few moments before beginning again. It was their theory that too much emphasis on left-brain verbosity skewed the reality of what they wished to talk about, so they enforced these 'moments of rest' in order to give Right Brain a chance to muse. These lectures were given by Alpert and Leary at the Esalen Institute in Big Sur, California, in the 1960 's.

It may therefore be that the Prophet himself (s.a.w.) sat down in the middle of each Friday sermon for a much more interesting purpose than merely to rest. Perhaps his genius already understood the different needs of the brain hemispheres, and by remaining silent for a few moments, he was encouraging non-verbal Right Brain to project itself into the occasion. This also assured that too much concentration on the left-brain verbal communication did not obscure whole-brain participation in the worship. The aesthetics of the Imam's chair in the Yogya Mosque would then be subliminal a reminder to the Muslims of the extreme, highly regal importance of Right Brain in the conduct of their religion.

Religious matters do not always impact people's lives very much through talking. Left-brain understanding at the verbal level is of course the foundation for adherence to the Shariat Law. But beyond that, we need a holistic understanding of 
the 'spirit of the law' that only Right Brain can give us. We should cherish our right-brain (silent) moments. It is by means of them that our moments of Qodar Ilham (private inspiration) descend and touch our souls. The emptiness of the interior of the Ka'aba in Mecca is said to symbolize the absolute silence and emptiness requisite of the human soul who longs to hear the Divine Voice.

Referring further to the importance of mosque aesthetics, a twenty-three-year-old Javanese male reported that he had performed one prayer while visiting Malaysia's Sultan Salahuddin Abdul Aziz Shah Mosque, a magnificent blue-domed structure that can accommodate upwards of twenty thousand worshippers. There, he had a profound aesthetic experience:

'When I was praying for the first time in the State Mosque in Selangor, I saw a beautiful white light coming into the mosque and surrounding all of the supplicants. I will never forget this experience.'

What this young man saw was, of course, an inner radiance, an aesthetic component that will doubtless impact all the rest of his praying life. The young man's father also reported seeing a brilliant light on the occasion of the death of his Javanese Ustaz ('Ustaz' or 'Ustad', from an Arabic word meaning 'respected teacher' or 'spiritual guide'):

'The night my Ustaz died, I was tormented all night long by visions of my sins and mistakes in life. It seemed that I had ruined every opportunity Allah had given me to do something good. I prayed to know what, if anything, might be accepted by Him of my various achievements in life, and one by one everything I offered was rejected. Finally, at the end of the night - which I will always call my 'Dark Night of the Soul' - it became time to pray the early-morning prayer. So I washed myself and prayed as usual. In the middle of this prayer, a great white spotlight came down onto my prayer carpet and held me in its brilliance until I had finished. This was my answer. This, at least, after all my agony that night, had been accepted. I have seldom missed any of my five daily prayers since this experience.'

Such experiences tend to remind us of the famous 'Light' passage in Al Qur'an:

'Allah is the light of the heavens and the earth. His light may be compared to a niche that enshrines a lamp, the lamp within a glass which looks as if it were a brilliant star. It is lit from a blessed olive tree, neither eastern nor western. Its very oil would almost shine forth, though no fire touched it. Light upon Light: Allah guides to His Light whom He will' (Surah 24, An Nur, Ayah 34 -36).

As a direct result of these experiences of a visionary 'light', both this man's and his son's religious practices were altered, more deeply inspired for perhaps the rest of their lives. The father's 'Dark Night of the Soul' (a phenomenon well known to Christian mystics as well) culminated with a vivid insight into why we pray, and why that prayer may be our only hope of redemption from the ceaseless and inevitable mistakes of our earthly life.

This father's son had his very first experience of a 'mystical light' while praying in the aesthetic masterpiece that is the Shah Alam Mosque. This son's experience will perhaps continue to remind him that the Unseen World really does exist and sometimes does intervene in our daily lives. The father-and-son sensitivity to these experiences also suggests a possible genetic susceptibility to aesthetic perceptions.

\section{The Aesthetics of Birth and Death in Islam}

The psychology of religion must include certain 'rites of passage' within its purview, those that impact very strongly upon one's religious feelings and convictions. For example, one of Freud's disciples, Otto Rank, took the 'birth trauma' as fundamental in formation of the later personality dynamics. Therefore, we will now report some field notes dealing with Islamic attitudes toward birth and death.

One informant reported an experience with his Javanese wife when she gave birth to their first child. They were living in San Diego, California, at the time, yet Muslim customs associated with childbirth asserted themselves. The father reported having a vision while still in Java of meeting the soul of this child in Paradise long before he was actually born, a typically Javanese mystical perception. But he was not sure of the truth of his vision until the beauty of the actual birth confirmed its veracity:

'We had not planned anything special. We went to the government hospital, but the first two times they sent us back home saying it was a 'false alarm'. Then I gave my wife some olive oil and lemon juice, a traditional remedy to smooth difficult births. I also prayed for the child to be safely born. When we went back the third time, she gave birth almost immediately. Then an amazing thing happened. Of course, the hospital staff knew we were Muslim, but I guess they did not expect anything from that. But when my son appeared, I was so moved that I immediately began to sing the Azan (call-to-prayer - ed.). And the amazing thing was that everybody in the delivery room simply stopped what they were doing, as if frozen in time. Our baby lay quietly on his mother's belly, before the cutting of the chord and without ever crying one single tear. Nobody tried to slap him. After my heartfelt Azan was concluded, the hospital staff moved into action again and completed their duties. I'm not really sure what stopped them and kept them quiet while I called the Azan. I 
doubt that any of them had ever heard of anything like that happening in the Delivery Room before. People later said our child was the most contented baby they had ever seen. He never cried at all until he was already several months old. I know people may not believe this, but it's true. And I think it is connected with how beautiful the Azan has always sounded to me, and my passing this beauty on to my son during his first few moments of life. And maybe this is what made him feel content, and why the Prophet ordered us to do this.'

Javanese fathers do not in general attend the birth of their children, however, western influence may be having a positive effect (for once) in changing their beliefs and practices, as in the case above. The traditional 'leave birthing to the women' was changed by implication 1400 years ago, when the Prophet (s.a.w.) ordered fathers of newborn Muslims to utter this prayer call into the ear of the child, presumably before all else. And what happens then to the 'modern' practice of slapping the baby to force it to breathe? An entire school of western (secular) psychology has been founded upon the 'birth trauma'. If Muslim practices minimize the trauma, such that newborn babies are not required to cry as evidence of the viability of their vital functions, we see that the Prophet Muhammad (s.a.w.) may again have been ahead of his time.

Aesthetically, the Prophet's advice makes perfect sense. Even a full-grown adult may respond more favorably to a prayer call than to a slap on the body. How much more sensitive would a newborn infant be, who has never yet registered anything from the outside world through the senses? Over the years, one of the most valued audience responses to my piano recitals has been the compliment, 'Reassuring'. Perhaps human beings have been given the sense of beauty as a form of reassurance.

In some Islamic funerals, this same call-to-prayer may be sung over the enwrapped body at the last moment before it is covered with earth. Here is how such a funeral affected one informant when he was a young man, studying in Cairo. He is now retired in the Yogya area, so one can see the lifelong influence of these 'funeral aesthetics':

'When I was a young man, I came across some villagers carrying the body of one of their deceased to the graveyard. They were reciting one short chapter from the Qur'an over and over again, not really a chant, not really happy or sad, certainly no wailing or carrying on emotionally. It was simply an acceptance of another of life's mysterious ways. I felt how suitable to die this way! How suitable that one's family and friends would tend to one's body, see that it was properly cleaned and wrapped in clean cloths, and placed respectfully into the earth before a final 'azan' is called over it. It was an aesthetic experience in my opinion because, to me, the Qur'anic verses along the way and the prayer call over the open grave were recited in that uniquely surrendered yet quietly persistent way that is the essence of Islam, and in a way that remains absolutely unforgettable in my memory. And this memory reassures me, it staves off any fear of death I might have. The quiet recitation of these Muslims expressed a continuity of life on this earth with whatever may follow. There was no break, no need for 'mourning' in any sense. And no need to pay money to strangers to take care of the bodies of their deceased, as westerners do. Why do they do that? Can't they see the superiority of our way?'

In Yogyakarta, if one joins the family and friends of a recently deceased family member, the body will be washed behind a clothe screen, during which the feelings are quiet, neither happy nor sad. If westerners walk through the area along the narrow 'gang' (a walkway meant for people but not vehicles), they are usually utterly oblivious to what is going on. They may never cease to chatter among themselves, nor look around, nor even register this solemnly beautiful occasion. One shares the pity which local people feel at the spiritual paucity of such westerners who themselves can only pay strangers to bury their dead inside of boxes. 'Mourning' among Muslims is a spiritual state of equipoise and surrender, utterly non-grasping, utterly timeless, that also seems to be nurtured and matured by the Islamic prayers. It is neither joy nor sorrow.

\section{The Aesthetics of the Unseen in Islam}

Anthropologists have devoted much study to the unseen worlds of various cultures, such as tribal myths and totems, or religious superstitions. However, most such study does not credit Revelation as signifying any reality more than imaginary. As western anthropology has it, religion is merely one aspect of culture, whereas for Muslims religion creates cultures.

As an example of the aesthetics of the Unseen, we will refer to a description found in one of the transcribed talks of Muhammad Subuh Sumohadiwidjojo which is available at the library of the Muhammad Subuh Foundation, South Jakarta. In his talk, a major figure of the Javanese unseen world is discussed - Nyai Loro Kidul, the Queen of the South Seas. If we assume her reality, as most Javanese do (at all levels of the society), we may thereby avoid discussions of the secular type and penetrate directly to the Queen as a model for the Javanese aesthetic sensibility. Doubts about her actual existence may be entertained by western researchers with other agendas.

The Queen's Islamic reality consists of her status as a royal jinn, responsible for the protection of all Javanese people, and with vast minions of subject-jinni organized under her command, for various tasks required in carrying out her 
responsibilities. These characteristics are well-known, but are not usually discussed seriously with outsiders. Here is Muhammad Subuh's story:

'We Javanese hold one of our forebears in great respect, that is, Panembahan Senopati, who is said to have been a great man whose name was held in high repute... When he went to visit Nyai Loro Kidul in her palace, he envied her. He was overwhelmed. He shook his head and asked,

'Is this your palace, oh Queen?'

'Yes, it is mine and I really own it, my love.'

It was so magnificent that everything was made of gold or covered with gold leaf. Then he was conducted to a bedroom.

'Is this your bed?'

'Yes, my love.'

'Incredible. There is nothing like this in my country, in the land of my people.

'Of course there is not. It would not be possible. That is why, if you are willing to do so, you should come and live with me in my environment, here in the world of the jinn. Apart from possessing all this and more, you will have a very long life, which will only end when this world comes to an end.'

Senopati nodded his head. At that moment, he was almost overwhelmed, Panembahan Senopati was almost overcome. Then he remembered the advice and instruction he had had from Sunan Kalijogo, his teacher.

'Oh Queen, I thank you very much for your affection and concern for me, but I am a human being, subject to death and to disease, and I possess only those things of beauty which exist in the world of human beings. So I cannot accept your offer. I must go back to being human.'

Nyai Loro Kidul wept. You must understand that she was on a very high level, as high as Panembahan Senopati. Then he returned home.

So, if Panembahan Senopati was almost overcome, how much more so for you. You are frightened of the beings who live under the bamboos. They can be really beautiful, yes. If they laugh, just to hear that laugh makes one forget everything.'

Painters of a mystical nature love to paint Nyai Loro Kidul. A photograph of one such painting is in this author's possession. She is always portrayed with great beauty, and it is this beauty that tempts mortals to give up their mortality and join her. But the theological problem is that she, and all who follow her, will cease to exist at the end of time, whereas human beings are still capable of redemption and eternal life. Following jinn is thus a Faustian bargain, which is why all forms of magical practice, such as learned from the Devil by Dr. Faustus in the western legend, are forbidden in Islam.

The beauty of Helen which tempted Faust in Goethe's retelling of the legend ('Faust - Part II') resulted eventually in a child born of Faust and Helen (Hyperion). Hyperion was the symbiosis of Helen's beauty and Faust's knowledge, which led the child ultimately to its own destruction, as if the archetypes 'beauty' and 'knowledge' could not safely coexist in one single human soul. Hyperion was moved by the beauty of the moon to jump higher and higher to reach it until he disappeared into the sky, unable to return to earth at all. The dangerously pervasive western value of striving for ever greater knowledge and power is well expressed in this image.

Javanese accounts of their encounters with unseen beings of great power often describe these entities as being either very beautiful or very ugly. An identity is suggested between beauty, goodness, and wisdom, or ugly, evil and stupid. This dualistic symbolism exists in the mythologies of many peoples. The Islamic message, not always heeded by Javanese Muslims, is that aesthetic beauty is not value-free and may in fact be utilized in very dangerous ways to entrap humans in various forms of misbehavior or forbidden belief. Javanese religious leaders such as Bapak Muhammad Subuh Sumohadiwidjojo, often warn against such dangers.

\section{Types of Human Cognition: Clash and Convergence}

How, therefore, can we understand the function of aesthetics, especially the aesthetics of religious peak experiences, as a fully legitimate and human need? We refer now to Islamic and Javanese models of 'ideal types' of cognition, far broader than aesthetics alone:

The four levels of the Islamic cognitive model are:

1. Shariat, or Islamic Law and Rituals, meaning those rules and regulations the faithful following of which will in itself assure Paradise for the sincere believer; 
2. Tarekat, or Islamic Devotions and Meditations, not obligatory but helpful in deepening one's faith and leading to expanding one's horizons of understanding;

3. Hakekat, or Islamic Insight and Inspiration, this being the fruit of the Tarekah properly applied; and,

4. Marifat, or Islamic Self-Actualization (called 'Insan Kamil' in Arabic, or 'the Complete Human Being', also described by Maslow as the 'self-actualized' person).

And now we must inquire as to the aesthetics appropriate to each of these four cognitive styles.

The aesthetics of religious practice (i.e., the Shariat) follow normal judgments of what is beautiful, both objectively and subjectively. The Grand Mosque at Mecca, especially as broadcast during Ramadan, is a compelling demonstration of the exquisite beauty that can nowadays be found completely within the limits of the Shariat law. The spectacle of thousands of worshippers prostrating together in Jakarta's Istiqlal Mosque is another example of the orderly, impressive beauty of uniform human action in supplication to the Creator. We have mentioned the Imam's chair in the Yogyakarta Royal Mosque as a thing of great beauty. One of the towers near the Royal Mosque in Solo, reputed to be a center for astral traveling, has a fascinating beauty that is quite unique. These are all examples of the visual aesthetics of the Shariat.

As for the aural beauty of the Shariat, Muslim worship is full of it, from the call-to-prayer through the Qur'anic recitations. The Qur'an explicitly orders Muslims to greet each other with the Arabic 'Salaam', which is music to any Muslim's ears, and also inspires various other melodious Arabic-Islamic expletives and expressions that permeate Muslim social intercourse. Some types of singing groups are regularly part of the intermission at the yearly International Qur'an Reciting Festival in Kuala Lumpur (called 'Nasyid', forming a significant music sub-industry in both Malaysia and Indonesia). Arab-inspired popular singing, called 'Dangdut', has been an integral part of Indonesian popular culture for many years, although it sometimes degenerates into 'haram' versions.

As for Tarekat aesthetics, duty and responsibility assure Paradise in Islam, not 'happiness', 'self-fulfillment', or other signs of worldly or even mystical success. (There is no 'sainthood' in Islam, although the tradition of exceptional beings still exists. They may be called 'Wali' in Sunni Islam, 'Ayatullah' in Shi'ite Iran, 'Kyai' in Indonesia, etc.) The mystic emphasis on 'realizing God' or 'absorption into the Godhead' is therefore only optional in Islam (i.e., not required by Shariat Law) but can still be approached through various methods of the Tarekat, some of the more famous of which are the Mevlevis ('Whirling Dervishes'), Nashqbandiyah, Qadiriyah, Chishtiyah, etc. Java's now-worldwide 'Subud' denies being a Tarekat though its founder, Muhammad Subuh Sumohadiwijojo, claims descent from one of the 'Nine Saints of Java' ('Wali Songo'), one Sunan Kali Jogo.

Some Tarekat, such as the Mevlevi 'whirling dervishes' of Turkey, practice a highly visual aesthetic, said to be derived from movements of the heavenly bodies that are so often mentioned in Al Qur'an as among the greatest of the signs and proofs of Allah's existence. Virtually all Tarekat groups use music or 'sound arts' as aids in attaining various forms of ecstasy or divine absorption. Followers of Subud use a combination of spontaneous movement and sound.

When 'zikir' (chanting in Arabic) occasionally climaxes into moments of 'Hakekat', or individual insight into the truth or reality of things, Tarekat aesthetics becomes very interior, such as in one's feelings towards birth and death when witnessing these events, or when sensing rather than perceiving other aspects of the Unseen World (jinn, angels, 'cosmic consciousness', etc.). There may even be said to be an 'aesthetic' of Divine Judgement, should one be capable of perceiving it through one's dismay.

As for the aesthetics of the Marifat, let us approach cautiously from the Javanese point-of-view, noting that Islamic scholars themselves may have trouble verbalizing this level. Of the seven levels of Javanese cosmology, the first four are expressed as 'material', 'vegetable', 'animal', and 'human'. Reading Bapak's translated talks in the library of the Muhammad Subuh Foundation in South Jakarta reveals various subtleties behind these designations.

At the material level, nothing moves - things repeat as they are, again and again, such as grains of sand or stone pebbles. Even material objects have a type of static awareness, which is the reason for their strong influence and hold upon the feelings of human beings, but they are incapable of any movement themselves. They must be made to move by vegetable matter growing, or by animals, or by humans.

At the vegetable level, the factor of organic growth is added, but not yet mobility. As a result of these 'rooted' growth processes, a certain further awareness is said to arise, aspirations occur. When a patient withdraws or 'implodes', we may describe him as 'vegetating' - we know he has awareness, but we can see no evidence in his behavior of what that awareness might be. He may grow organically, yet he does not move physically, or emotionally for that matter. One is reminded of the Javanese 'bertapa' meditation, a total stillness which was said to be often prescribed by the Wali Songo (Nine Saints) as a test of spirituality.

At the animal level, we get growth plus mobility. Animals can move around, and it is this energy that we take from eating their flesh that gives us the power to work, think, invent things, and so on. We may surmise that animals have a 
certain awareness of moving, yet nothing of the meaning of their movement. Even so, as the previous rooted vegetable awareness now suddenly moves about, perhaps an explosion occurs - 'I can move! I can move! I am free! I am free!'

Only at the human level, however, can any real understanding of meaning be said to arise, and only if the forces from the lower levels have not distracted our attention in their envy and grasping for recognition at our unique level. And what is that unique level? It is the level 'Insan Kamil' referred to in Al Qur'an.

When the jinn and angels complained to Allah swt that Adam, the first man, was only made of mud, so why should he be superior, Allah swt commanded all lower-level beings to bow or prostrate before Adam, and ordered Adam to tell them the names of things as proof that he had superior knowledge directly from Allah. The Prophet Adam (a.s.) remains a Prophet or 'Nabi' in Islam, rather than committing any irrevocable sin that has tainted all of his progeny. He is, in fact, a model for Islam's 'Insan Kamil', the human being who is superior and complete because he has the gift of language the names of things.

And the 'Name' Adam knew with which we are concerned here is 'beauty'. Aesthetic sensibility is one of the unique signs of true humanity. Lower levels do not know it. It destroys or maims no one. It ennobles all who recognize it. Qur'an constantly describes the signs of nature's beauty as proof of divinity, and insists that these signs are far more important than miracles. This is the deep significance of Islamic aesthetics. The Qur'an repeatedly asks, is the natural beauty of the cosmos itself not enough to inspire faith? Those blessed genetically with aesthetic sensibility may therefore have higher hopes of obtaining faith. Or, one may say that the appreciation of true beauty is one of the legitimate paths leading to belief in the Almighty.

So this is the prototype for the Marifat - Prophet Adam's life on earth that is in complete harmony with the Seven Heavens and their Creator. Marifat aesthetics therefore involves both behavioral and spiritual elements. Marifat aesthetics is holistic aesthetics, uniquely accessible to what the Javanese call 'the human level'. We all have some knowledge of mineral, vegetable, and animal heavens and energies. Some of us may achieve the human level, or even higher.

According to the Javanese, there are three levels above the human which may be beyond our reach to all save the saints, walis, and prophets. Both Islam and Javanese philosophy contend that the truly human level is already difficult enough to attain, and that such higher levels as may exist should be of no more than of theoretical interest to us, not to mention that they may be totally impossible to imagine in any case.

Goethe might classify these 'higher levels' as 'Faustian', leading ultimately to signing your soul over to the Devil himself. Or, in another excellent example of 'cultural convergence', Shakespeare put it well in his 'Macbeth' (I,vii):

I dare do all that may become a man; Who dares do more, is none.

The Prophet Muhammad (s.a.w.) was once approached by a simple man, who asked him whether, if he attended well to his five daily prayers, his Ramadan fasting, his charity, and his journey to Mecca, And Did Nothing Else, would he be admitted to Paradise? The Prophet (s.a.w.) replied, 'Yes'.

As a stage on the path toward spiritual insight, a methodology of Tarekat will hopefully lead to the 'Hakekat' of sudden apprehension of truth or reality in the patient's life - the meaning of what he has been doing or avoiding all these years. Integration is then the meeting of 'inner' and 'outer', or, in religious terms, the harmonization of THIS world with the next -- there is no longer any distinction between heaven and earth. If 'Hakekat' is the sudden explosion of insight, 'Marifat' is walking down the street in perfect harmony with that insight. Nothing can shake it, for a while at least. It IS attainable, and it is mentally healthy.

The Muslim must sit perfectly still during the Imam's sermon at the Friday prayer. His eyes are supposed to be focused at the point on the carpet before him, where his forehead will subsequently touch down in the full prostration, and they must not wander. Every single move of the Muslim prayer ritual must come to a complete mini-implosion of rest before the next movement, there is no flowing through all this as some appear to do it. They are mistaken. The Prophet instructed us to stop at each stage of the prayer movements before going on to the next.

The 'explosion' following the extreme inwardness of the month of fasting is even more impressive, on the Idul Fitri holiday that marks the end of Ramadan. Technically speaking, the Hajj is the proper expression of the 'explosion' following a successful fasting month, such that the Ramadan straight through until the Hajj month form an interlocking cognitive unit, a yearly training in cognitive mobility. 'Integration' is the obvious yet difficult process of bringing the spiritual lessons and benefits gained from the fasting and pilgrimage months into subsequent daily work and family life.

In arriving at the Marifat, or the 'gnosis' of the Human Level, we are suggesting a convergence of cultures. If we rise high enough on the aesthetic scale of any religion, aesthetic experiences may be said to fall into the category of 'peak experiences', able to transform attitudes, values, and human behavior. As such, what the Muslims call 'Marifat' is the precise antidote to 'culture clash'. And it is this point at which Islam becomes fully inclusive of human life, instead of parochially exclusive, defensive, and often violent. 
Arturo Toscanini was a superstar orchestra conductor of the first half of the twentieth century. Here is what was written about him after he died:

'There are those who say that late last night, in Carnegie Hall, long after Toscanini and his orchestra and his listeners had gone to their refreshment or their rest, and the doors had been shut and bolted, and the lights put out, a group of Immortals gathered in the darkness and the quiet of the auditorium. It seemed as though infirmity had dropped from them. One, no longer deaf, listened quietly to one whose pain had gone; and this one, more easily articulate than the rest, was heard to say - it seemed with incredulity - 'I am he that liveth, and was dead.' - (Lawrence Gilman, Music Critic, New York Herald Tribune, 4-30-36)

In one essay, the American philosopher Leo Strauss writes:

'When we attempt to return to the roots of western civilization, we observe soon that western civilization has two roots which are in conflict with each other, the biblical and the Greek philosophic, and this is to begin with a very disconcerting observation. Yet this realization has also something reassuring and comforting about it. The very life of western civilization is the life between two codes, a fundamental tension... But this comforting thought is justified only if we live that life, if we live that conflict. That is, no one can be both a philosopher and a theologian, or, for that matter, a third which is beyond the conflict between philosophy and theology, or a synthesis of both. But every one of us can and ought to be either the one or the other, the philosopher open to the challenge of theology or the theologian open to the challenge of philosophy.'

In this essay, which appears in 'What is Political Philosophy? And Other Studies', Strauss elevates religious revelation to an equal level with rational thought as a legitimate source of knowledge.

We have attempted to examine aesthetics as a major component of religious revelation, and therefore a significant motivational factor in religious conversion and subsequent spiritual growth. We hope to further the discourse regarding the aesthetic persuasiveness of Revealed Knowledge, long familiar to traditional religious cultures, that is now proceeding even in the western world, as evidenced by these words of both the contemporary American philosopher and the contemporary American music critic.

\section{References}

Al Faruqi, L. L. (1986). Islamization Through the Sound Arts. American Journal of Islamic Social Sciences, 3 (2)

Al-Attas, S. N. (1998). The Worldview of Islam. Kuala Lumpur: Institute for Islamic Thought and Civilization.

Badri, M. (2000). Contemplation - An Islamic Psychospiritual Study. Kuala Lumpur: Medeena Books.

Bateson, G. (1972). Steps Toward an Ecology of Mind. New York: Ballantine Books.

Catalog for Exhibition. (2000). Insyirah. Kuala Lumpur: Petronas.

Dufford, S. (1982). Improvisation Training: The Principles and Applications of the Performance of Spontaneous Music on the Gamelan. Unpublished Master Dissertation, Antioch University Press, Antioch, Ohio.

Ibn Khaldun, Muqaddimah, Translated by Franz Rosenthal, Princeton University Press, Princeton, NJ, 1967, Vol. 2.

Jourdain, R. (1997). Music, The Brain, And Ecstasy. New York: Avon Books.

Maslow, A. (1976). Religion, Values, and Peak Experiences. New York: Penguin Books.

Nasr, S. H. (1991). Islamic Art and Spirituality, in Sufi Essays. New York: State University of New York Press.

Ornstein, R. (1997). The Right Mind: Making Sense of the Hemispheres. Orlando: Harcourt Brace.

Qutb, S. (1979). In the Shade of the Qur'an. London: MWH Publishers.

Santayana, G. (1961). The Sense of Beauty - Being the Outline of Aesthetic Theory. New York: Collier Books.

Scruton, R. (1997). The Aesthetics of Music. Oxford: Oxford University Press.

Soleri, P. (2001). What If? - Collected Writings 1986 - 2000, Book Two, Esthequity and Religion. San Francisco: Berkeley Hills Books.

Sullivan, J. W. N. (1960). Beethoven - His Spiritual Development. New York: Vintage Books. 